\title{
Energy retrofit of historic and existing buildings. The legislative and regulatory point of view.
}

\author{
LIVIO MAZZARELLA \\ Politecnico di Milano, Dipartimento di Energia, Via Lambruschini, 4 (20156) Milano, Italy
}

Corresponding author: Livio Mazzarella, tel. +39 022399 3869, fax +39 022399 3868, e-mail: livio.mazzarella@polimi.it

\begin{abstract}
The building sector is one of the key consumers of energy in Europe; consequently, European Union has enacted several Directives dealing, directly and indirectly, with energy efficiency in building aiming to reduce the buildings energy use. Those directives, while dealing with existing buildings, do not take care of the Architectural Heritage in a specific uniform way adopting the derogation regime: exceptions are available at the national level to exclude from their application buildings listed in the Architectural Heritage as historic buildings. Thus any country can adopt its own rules to include or exclude buildings from respecting the energy efficiency requirements for existing buildings. Consequently, up to now no general rules, codes and standards are available for energy retrofit of historical and architectural valuable buildings. On the other side, no international act, in the field Architectural Heritage conservation, deals with energy and energy retrofit. Furthermore, the European Union Treaty does not comprise the Cultural Heritage as matter of European legislation. Thus to cover this gap between historic/historical building and energy retrofit a lobbying action is needed, managed by the national Cultural Heritage authorities, which can steers EU policy in a more effective way towards energy retrofit of historic/historical buildings.
\end{abstract}

Key words: Energy, retrofit, historic building

\section{Introduction}

The building sector is one of the key consumers of energy in Europe where energy use in buildings has seen overall a rising trend over the past 20 years. It is estimated that there are 25 billion $\mathrm{m}^{2}$ of useful floor space in the EU27, Switzerland and Norway with a gross floor space equivalent land area to that of Belgium $\left(30,528 \mathrm{~km}^{2}\right)$. Non-residential buildings account only for $25 \%$ of the total stock in Europe, but comprise a more complex and heterogeneous sector compared to the residential sector. 
In 2009, European households were responsible for 68\% of the total final energy use in buildings. Energy in households is mainly consumed by heating, cooling, hot water, cooking and appliances where the dominant energy end- use (responsible for around 70\%) in homes is space heating [1].

Several actions have been taken by the European Commission to reduce this energy consumption through two Energy Performance Building Directives: Directive 2002/91/EC [2]and Directive 2010/31/EU [3], shortly EPBD and EPBD recasting. While the first Directive was more focused on methodologies and new buildings (i.e. new constructions), the second is giving more importance to the existing buildings not only when subject to major renovation but also when building technical elements and/or technical systems are retrofitted or replaced.

This major attention to the existing buildings relates to the low annual growth rates of new constructions, which in the residential sector are around $1 \%$ while most countries encountered a decrease in the rate of new build in the recent years, reflecting the impact of the current financial crisis on the construction sector [1]. Nowadays it is very evident that, to reduce fossil fuels consumption and $\mathrm{CO}_{2}$ production in the building sector, the challenge is to reduce existing buildings energy needs.

In fact, a substantial share of the stock in Europe is older than 50 years with many buildings in use today that are hundreds of years old. More than 40\% of our residential buildings have been constructed before the 1960s when energy building regulations were very limited. A large boom in construction in 1961-1990 is also evident through our analysis where the housing stock, with a few exceptions, more than doubles in this period [1].

\section{FIGURE 1}

Data on typical heating consumption levels of the existing stock by age shows that the largest energy saving potential is associated with the older building stock where in some cases buildings from the 1960s are worse than buildings from earlier decades. The lack of sufficient insulation of the building envelope in older buildings was also reflected through the historic U-value data, which comes with no surprise, as insulation standards in those construction years were limited [1].

The average specific energy consumption in the non-residential sector is $280 \mathrm{kWh} / \mathrm{m}^{2}$ (covering all end-uses), which is at least $40 \%$ greater than the equivalent value for the residential sector. In the nonresidential sector, electricity use over the last 20 years has increased by a remarkable $74 \%$ [1].

\section{FIGURE 2}


After the EPBD and the EPBD recasting entered into force, member states have shown an increased interest in interventions aimed to obtain energy saving in existing buildings. This resulted in an explicit article on building renovation in the Energy Efficiency Directive 2012/27/EU [4].

All these considerations drive to the conclusion that energy retrofit of existing buildings is a very important challenge in reducing energy consumption, but such opportunity has to be managed carefully. The wide variety of existing building, age by age, does not allow having a unique approach to the problem as it is possible for new constructions. This is mainly the case of historic buildings, which, while belonging to the existing building category, have to be treated in a very specific way, usually case by case. For instance, an open question is the definition of "historic building" itself and the reasons for which it has to be treated differently or not from an "ordinary” existing or "historical” building. Another important point is that there is variety of terms used in the building sector which may overlap; thus it is important to clarify what exactly is a retrofit, and how it differs from a renovation or a refurbishment.

While in Appendix A definitions are reported to clarify the meaning of such last terms, the question of what a historic building is will be addressed in the following.

\section{Historic buildings versus historical and contemporary existing buildings}

"Historic" is an adjective that means something important or influential in history, while "Historical”, on the other hand, it is an adjective that refers to anything from the past. Thus, a historical building is one that is related to history but may be not important at all from the History’s point of view, whereas a historic building is important by definition.

The simplest definition of a historic building is that related to three essential attributes [5]: to be considered "historic," a property must have sufficient age, a relatively high degree of physical integrity, and historical significance.

Age: A property must be "old enough" to be considered historic. Generally speaking, this means that a property must be at least 50 years old, although this is just a general rule of thumb. Another way of looking at it is that a property must be old enough to have been studied by historians, architectural historians, or archaeologists so that its place in history is clear. This latter perspective allows some types of properties that are less than 50 years old to be considered "historic."

Integrity: In addition to having sufficient age, a property must retain its historic physical integrity. For a building, structure, landscape feature, historic site, or historic district, this means that the property must be relatively unchanged. Its essential character-defining features relative to its significance must still be present. For an archaeological site, integrity means that the site must be relatively undisturbed, with its patterns and layers of artefacts and other archaeological evidence relatively intact. For a traditional cultural property, integrity means that the site must be recognizable to today's affiliated cultural group, evidenced through tradition, and still used or revered in some way. 
Significance: Finally, and most importantly, a property must be significant to be considered historic. Significance is defined in three ways: (1) through direct association with individuals, events, activities, or developments that shaped our history or that reflect important aspects of our history; (2) by embodying the distinctive physical and spatial characteristics of an architectural style or type of building, structure, landscape, or planned environment, or a method of construction, or by embodying high artistic values or fine craftsmanship; or (3) by having the potential to yield information important to our understanding of the past through archaeological, architectural, or other physical investigation and analysis.

But, this is a starting point and not a final solution. Up to now there is no a specific common "scientific" way to “objectively” define a grade for such necessary attributes but not sufficient at all. There is today a great effort to try of unifying such decisional process, but, at the end, it is based on discretionary measures.

Here a distinction had been introduced between historic and historical buildings. The reason for that is a simple one: generally special national and/or local laws protect historic buildings and any rehabilitation (no renovation at all) cannot be carried out without special permission from the local planning authority, which typically consults the relevant central government Cultural Heritage agency. They are officially part of the architectural heritage. Thus, also any energy retrofit has to be analysed and authorised by such authority. In UK this type of buildings are also called “listed building”, because are just reported in a special list, as in other Countries like Italy.

Historical building, on the other hand, may be potentially historic building but they do not have such status jet and thus do not have any protection by default. Usually a national dependent procedure has to be followed to possibly get the status of historic building.

Finally the existing buildings, which the Energy Efficiency Directive [4] is referring to, are not just old buildings, which can undergo to the renovation process to improve their quality and fix the new standards (contemporary existing buildings), but they comprise also of the historic and historical buildings, for which renovation (as defined in Appendix A) is not allowed or not desirable.

This is making the energy retrofit of existing building a not straightforward process. In fact, within an energy retrofit in architectural heritage is necessary to undertake completely different operations in some aspects from the same interventions carried out in contemporary existing buildings. However, the current interventions often include criteria that is inapplicable on historic buildings, even when being fully compliant to the energy saving aims. This is because the regulations concerning preservation of architectural heritage and rational use of energy are not linked to each other, and because within European standards a protocol for energy retrofit and the definition of its feasibility within historical and heritage buildings is still missing [6].

\section{Regulations concerning preservation of architectural heritage and rational use of energy}




\subsection{Architectural heritage regulation}

At the world wide level, the only regulation dealing with Architectural Heritage is the UNESCO's Convention Concerning the Protection of the World Cultural and Natural Heritage [7], which was drawn up in 1972 and ratified by 190 States at Sep. $19^{\text {th }}$ 2012. This convention notes that the cultural and natural heritage is increasingly threatened with destruction. Each state party to the convention recognises that the duty of ensuring identification, protection, conservation, presentation and transmission to future generations of this heritage belongs primarily to that state.

At the European level from 1969 until 2001 several conferences of ministers for heritage preservation and management were held with the aim of rethinking the European heritage in a sustainable perspective [6]. Before these, in 1963 the Parliamentary Assembly of the Council of Europe took the initiative in promoting European intergovernmental cooperation for the safeguarding and development of the cultural heritage of monuments and sites. Soon after the first European Conference of Ministers responsible for this sector held in Brussels between 25 and 27 November 1969 [8], the Assembly adopted Recommendation 589 in 1970 drawing the attention of the Committee of Ministers of the Council of Europe to the desirability of setting up a standing committee on co-operation, preparing a European charter setting forth the "general principles of the preservation and rehabilitation" of the heritage and then, in the light of the charter, preparing a European convention.

The follow up of this Recommendation was the European Charter of the Architectural Heritage, which was solemnly proclaimed at the Congress on the European Architectural Heritage held in Amsterdam from 21 to 25 October 1975 [9]. This Charter, together the Conference Declaration, states the principle of the integrated conservation: "integrate conservation in town planning, preserve groups of historic buildings and their environment and take the heritage into account as a part of economic and social life".

The national commitment to the protection of the architectural heritage were finally stated by the Convention for the Protection of the Architectural Heritage of Europe [10], drawn up by the Council of Europe, signed at Granada in 1985, and today ratified by 41 European Countries. Commonly known as the Granada Convention, it is a means of proclaiming conservation principles, including a definition of what is meant by architectural heritage such as monuments, groups of buildings and sites. It seeks to define a European standard of protection for architectural heritage and to create legal obligations that the signatories undertake to implement. Two are the most important points stated in this Convection: protection at transnational level, as part of a unique European heritage, and extension of the protection also to "not yet" protected buildings.

At Helsinki conference in 1996 [11] a resolution was made to establish a European methodology for heritage management in a framework of sustainable development, which had to be based on public-private practices aimed not only at architectonic preservation, but at a whole "building stock life cycles to assess the environmental impact of rehabilitation 
of old buildings compared to buildings constructed according to modern production methods". This approach, during the Hanover conference [12], was introduced in a more complex urban ecosystem management based on optimizing water, energy and waste.

These conferences held from 1969 through to 2001, raised awareness in considering a sustainable perspective for heritage buildings; but the above described developed insights, weren't effectively translated within the first EPBD [2], [6]. The technical problems related to the energy retrofitting feasibility within a historic context were almost neglected or generally derogated (see next paragraph). In 2005, during the Faro convention solutions to overcome this detachment were proposed [13], (art. 9, letter c, "ensure that all general technical regulations take account of the specific conservation requirements of cultural heritage") and once again in 2010 when the first EPBD recast [3], was published, the initial weak points regarding the matter had still not been updated.

After eleven years from the first European directive on energy and after seventeen years from the pioneering conference in Helsinki, technical standards or specifications to clarify the heritage buildings' position on their potential sustainable development have not yet been published by European Commission [6].

\subsubsection{The Italian example}

In Italy, a number of acts, plans, national and local guidelines have been produced on Cultural Heritage Conservation, dealing specifically with Architectural Heritage Conservation. In Italy, the growing debate on the principles and procedures of restoration has led to the adoption in 1939 of the two fundamental protection laws: Law 1089 for objects of artistic and historical interest and Act 1497 " Protection of natural beauty" revised and updated in legislative Decree 490/1999 the "Consolidated laws in the field of cultural and environmental heritage." Within this norm is defined as restoration of a work action "in order to maintain the integrity of the material and to ensure the preservation and protection of its cultural values". The Framework Law on cultural heritage currently in force is the Legislative Decree 42/2004 "Code of Cultural Heritage and Landscape” [14]. This code defines what cultural heritage, cultural and landscape assets mean. "Cultural heritage are the immovable and movable objects that, in accordance with Articles 10 and 11 are artistic, historical, archaeological, ethno-anthropological, archival and bibliographic, and other objects identified by law or under the law as evidence of value to civilization". "Landscape assets are properties and areas referred to in Article 134, constituting an expression of the historical, cultural, natural, morphological and aesthetic values of the land, and other assets identified by law or under the law”. Architectural and Building Heritage are protected by this Law or as a part of the cultural heritage or as landscape assets.

Under the Cultural Heritage umbrella, by art.10 paragraph 1 of the code [14] buildings owned by State, Regions, other local governments, as well as any other public body and institution and non-profit private legal entities, presenting artistic, historical, archaeological or ethno-anthropological values, are cultural assets by default and subjected to "monumental" 
constrain, i.e. they are "historic” buildings “ope legis”, if they were just more than 50 years old (paragraph 5), recently raised up to 70 years by Law 106/2001. For similar buildings owned by different legal entities, i.e. historical building, (paragraph 3), they may become "historic" only after the "Declaration of Cultural Interest”, which is a procedure able to recognize, from the point of view of legislation, the cultural and historic value of a given property; and therefore they are subject to appropriate protection requirements. Vice versa, a by default historic building may be declassed just to old existing building though an inverse procedure, "Verification of cultural interest”, which provides for a specific assessment of its historical and artistic interest. If this valuation is positive, the building remains forever under the discipline of protection, if negative, it is not anymore under those rules, i.e. the building is just old and it is no protected anymore. Both this procedures as any other permission on protected buildings are under the responsibility of a governmental specific authority, named “Soprintendenza” (Superintendence). For those buildings, any retrofit activity is subject to the issuance of clearance by the Superintendence for Architectural Heritage.

Under the Landscape umbrella, by art. 136 paragraph 1 letters b) and c), buildings, town centres and historical complexes having aesthetic and traditional value can be declared Landscape Assets and therefore they are subject to appropriate protection requirements. In this case the assessment procedure to get the "declaration of significant public interest” is quite complex. Because of an overlap with the conservation of historic buildings as part of the urban planning legislation, the implementation of landscape protection is a coordinated action between Regional Governments and the Regional Offices of the Superintendence for Architectural and Landscape Heritage. By requirement of art. 143, each Region has provided a Regional Landscape Plan (PPTR), which is a territorial development plans with specific consideration of landscape and environmental values, imposing constraints and requirements directly effective against individuals and municipalities. The R.L.P., together with the Provincial Coordination Landscape Plan (PTCP) (province is a land partition of a region, like a county), define strategies for territorial development and identify possible courses of action that provide the basis for municipal planning. Therefore, the municipal urban planning act, named "Piano Regolatore Generale” (PRG), together with the PTCP, are acts inside which the protected buildings are or have to be listed. Then specific actuation rules are reported in technical municipality regulations, like "Regolamento Urbanistico Edilizio” (RUE), specifying what kind of intervention can be made (rehabilitation, refurbishment, etc.) on any listed building category.

\subsection{Energy Efficiency regulations}

At the European Union level two main directives, the Energy Performance Building Directives, Directive 2002/91/EC [2] and Directive 2010/31/EU [3], had and have a key part of the EU legislation aiming to reduce energy consumption, which reaches about $40 \%$ in buildings. Since the first EPBD directive "major renovations of existing buildings above a certain size” has been regarded "as an opportunity to take cost effective measures to enhance energy performance”, not only 
for the whole building but also for "those parts that are most relevant for the energy performance of the building and are cost-effective". It was also underlined that "renovation requirements for existing buildings should not be incompatible with the intended function, quality or character of the building”. Only the first statement was reflected in an article, art. 6 Existing Buildings. The second was only, indirectly and weakly, taken into consideration in art. 4 stating that "Member States may decide not to set or apply the" energy "requirements" "for the following categories of buildings":

- buildings and monuments officially protected as part of a designated environment or because of their special architectural or historic merit, where compliance with the requirements would unacceptably alter their character or appearance,

- buildings used as places of worship and for religious activities,

- .. etc.

With the second EPBD directive, the recast, a bit more focus was made on the existing building just specifying that "for reasons of cost-effectiveness, it should be possible to limit the minimum energy performance requirements to the renovated parts that are most relevant for the energy performance of the building." This statement resulted in a modified art. 7 - Existing Building, which specifies that the energy performance requirements, specific for existing buildings, "shall be applied to the renovated building or building unit as a whole. Additionally or alternatively, requirements may be applied to the renovated building elements". When a building element "is retrofitted or replaced, the energy performance of the building element" have to meet the "minimum energy performance requirements (for that element, Ed.) in so far as this is technically, functionally and economically feasible”. That means that only technical, functional and economic reasons can avoid fulfilling the energy performance requirements, not reasons related to historical, cultural or landscape heritage. The last, important, addition on this article is that "Member States shall encourage, in relation to buildings undergoing major renovation, the consideration and taking into account of high-efficiency alternative systems, as referred to in Article 6, in so far as this is technically, functionally and economically feasible”.

Regarding to the exempted building categories, Article 4 was only revised respect to the wording, and it has been rewrote as:

- buildings officially protected as part of a designated environment or because of their special architectural or historical merit, in so far as compliance with certain minimum energy performance requirements would unacceptably alter their character or appearance,

- .. etc.

Then important references are made to existing building when dealing with Nearly Zero Energy buildings (art. 9, point 5): the Commission shall propose measures to "encourage best practices as regards the cost-effective transformation of 
existing buildings into nearly zero-energy buildings"; and with the introduction of the completely new art. 8 - Technical building system.

This new article states that "Member States shall, for the purpose of optimizing the energy use of technical building systems, set system requirements in respect of the overall energy performance, the proper installation, and the appropriate dimensioning, adjustment and control of the technical building systems which are installed in existing buildings." "System requirements shall be set for new, replacement and upgrading of technical building systems and shall be applied in so far as they are technically, economically and functionally feasible.” In addition, intelligent energy metering and automatic control systems shall be encouraged to be used.

Another directive, Directive 2012/27/EU on Energy Efficiency [4], in its art. 4, is specifically addressing the building renovation stating with art. 4 that "Member States shall establish a long-term strategy for mobilising investment in the renovation of the national stock of residential and commercial buildings, both public and private”. This because the rate of building renovation needs to be increased, as the existing building stock represents the single biggest potential sector for energy savings.

Furthermore, because buildings owned by public bodies account for a considerable share of the building stock and have high visibility in public life, it was therefore considered appropriate to set an annual rate of renovation of buildings owned and occupied by central government on the territory of a Member State to upgrade their energy performance. This renovation rate has been then set to $3 \%$ the total floor area of heated and/or cooled buildings owned and occupied by its central government each year (article 5). The main point is that this renovation has to comply with the minimum energy performance requirements established by application of Article 4 of Directive 2010/31/EU [3].

To avoid trouble with historic building, in point 2 of art. 5 it is again stated that "Member States may decide not to set or apply the requirements referred to in paragraph 1 (3\% renovation rate, Ed.) to the following categories of buildings:”

- buildings officially protected as part of a designated environment or because of their special architectural or historical merit, in so far as compliance with certain minimum energy performance requirements would unacceptably alter their character or appearance,

- $\quad$. etc.

Then, as it was anticipated, the technical problems related to the energy retrofitting feasibility within a historic context were almost neglected or generally derogated. No any mention how to improve energy efficiency in historic building while preserving their "function, quality or character". 


\subsubsection{The Italian example}

In Italy the Legislative Decree of 19 August 2005, n. 192 [15], implementation of Directive 2002/91/EC on the energy performance of buildings, as amended by Law 90/2013 [16], due to the implementation of Directive 2010/31/EU, provides in the same way a derogation regime for the cultural heritage.

The Article 3 states at paragraph at paragraph 3., 3-bis and 3-bis. $1^{1}$ that historic buildings have to comply with the EPBD requirements limited to energy certification and operation, maintenance and inspection of technical installations, as long as Superintendence for Architectural and Landscape Heritage is providing a negative judgment on the possibility to undergo to any renovation without altering unacceptably their character or appearance. If the judgment is positive, they are subjected to all EPBD requirements for existing building and no grading on their application is provided in the Law up to now.

Thus in the Italian law a derogation regime has been implemented for historic (i.e. protected) buildings as foreseen in the EPBD directive, which is based on the judgment of the competent authority. However, the Law does not specify how to comply with the EPBD requirements if the historic (i.e. protected) building may partially undergo to renovation or only rehabilitation or restoration.

No mention at all to those building which are comprise in the category of historical buildings (i.e. potentially declarable protected), which are equated to the contemporary existing buildings.

In Italy the EPBD requirements for existing building, which undergo to renovation, are today the following.

In the case of existing buildings renovation, and as far as the minimum required energy performance, a gradual application is expected in relation to the type of intervention:

a) a full application to the entire building in the case of:

1. complete refurbishment of the building elements forming the envelope of existing buildings with an useful floor area of more than 1,000 square meters;

2. demolition and reconstruction (redevelopment) of existing buildings with an useful floor area of more than 1,000 square meters;

b) a full application, but limited to the building enlargement when this enlargement is volumetrically more than 20 per cent of the existing building;

${ }^{1}$ 3. The following categories of buildings are excluded from the application of this Decree:

a) buildings that fall under the regulations of Part II and Article 136, paragraph 1, letters b) and c) of Legislative Decree 22 January $2004 \mathrm{n}$. 42 , the b)

Code of the Cultural Heritage and Landscape, as amended by paragraph 3-bis; (i.e. building declared to be historic building)

3-bis. For buildings referred to in paragraph 3, letter a), this Decree shall be limited to the provisions relating:

a) the energy performance certification, referred to in Article 6;

b) operation, maintenance and inspection of technical installations, referred to in Article 7.

3-bis.1. The buildings referred to in paragraph 3, letter a), are excluded from the application of this Decree, pursuant to paragraph 3-bis, just in case implies that the requirements substantially alter their character or appearance, with special reference to the historical, artistic and landscape values, as it must be judge by the Authority the authority which is in charge of the authorization according to Legislative Decree 22 January 2004 n. 42. 
c) a limited application in respect of specific parameters, performance levels and requirements, in the case of interventions on existing buildings, such as:

1. total or partial renovation, extraordinary maintenance and volumetric enlargement of the building other than those already provided in letters a) and b);

2. installation of new heating systems in existing buildings, renovation of these facilities;

3. replacement of heat generators.

\section{TABLE I}

In table I, the required limiting values of envelope parameters for existing building under case $\mathrm{c}$ ) are reported as function of the climatic zone (Italy has been divided in several different climatic areas), while the requirement for the installation of new heating systems or its renovation is defined through a minimum yearly average value of the overall system efficiency as:

$$
\eta_{\text {sys,ave }} \geq\left(75+3 \cdot \log _{10} P_{n}\right) \quad \%
$$

where $P_{\mathrm{n}}$ is the useful thermal power of the heat generator(s) in $\mathrm{kW}$. No limits have been set up until now for cooling.

\section{Risk for energy retrofit in historic and historical buildings}

Despite derogations for officially protected buildings quoted in Article 4 of EPBD [2] and in its recast, [3], and repeated in the Energy Efficiency Directive [4], these interventions are also rising in regards to historical fabrics [6].

According to a recent study made by Building Performance Institute of Europe, "minor and moderate interventions might be performed also in case of heritage buildings” in order to achieve Energy and $\mathrm{CO}_{2}$ reduction by 2050 [1]. In fact they say that "these buildings are not excluded (from the energy renovations, Ed.) because there will always be some energy efficiency measures that can be applied, even if it is not a total renovation. Minor and moderate measures may often be feasible in the case of heritage buildings". If on one hand the energy retrofitting in existing buildings is considered challenging because of the significant opportunities for reducing primary energy consumptions, then on the other hand the problem in linking energy improvement to building protection arises when the intervention is carried out in historical buildings [17], [18].

The main point is how to identify the "unacceptable alteration" the EPBD directives is referring to or "the minor and moderate interventions" that might be done [1]. "Which kind of materials or interventions might be considered detrimental for the building itself? Who and which instruments are capable of defending the unacceptable alteration due to the energy retrofits interventions in historical buildings? 
In fact, while a lot of technologies for energy retrofit in existing buildings are available today, [19] a large part of these solutions cannot be applied if preservation issues have to be considered, [6], [17], [20], [21], [22]. Furthermore, despite the big amount of CEN standards aimed at providing methodologies for energy performance calculation in new and existing buildings [23], no standards or methodologies have been delivered up to now in order to clarify the allowable retrofitting methodologies for historical buildings or to define the intervention boundaries (allowed materials, allowed techniques) [24]. Only recently CEN TC 346 (Conservation of Cultural Property) technical committee has started a working group, WG 8 "Energy efficiency of historic buildings" to write a standard on this item. This standard is supposed to be procedural, rather than defining general solutions. It should show a harmonised, systematic approach to facilitate the best decision in each individual case [25].

In Italy this point has only partially been solved involving the competent Authority to declare if or if not a historic building may undergo to a full or partial renovation, but there are no general rules to define all the intermediate cases (rehabilitation, restoration, etc.) and what are the most compatible available energy retrofit technologies.

Today European Union leaves this duty to the local Bodies, which it may be correct on one hand, but it might lead to a different interpretation in the intervention evaluation on the other hand. If no shared EU methodologies aimed at evaluating the level of tolerance are provided, we can run the risk of judging differently each retrofit strategy: more acceptable in one country as opposed to another [6].

For instance, in France, the Ministry of Culture and Communication requested exemptions for more than protected buildings. They wished exemptions for protected environments (cultural \& natural), the surrounding perimeter of historic monuments, for 'classed' sites, for UNESCO sites and for buildings protected by regional authorities, for buildings recognised as XX-century heritage, for apartment houses under art L123-1-2 of the urbanism code and for apartments that have elements that are of historic interest. But the result was a national French regulation that granted exemption only to buildings protected under the Cultural Heritage Act, and only on condition that window changes would modify or change their character in an unacceptable manner [26].

Furthermore, the major concerns are those related to historical buildings (i.e. buildings that may have historic value but not already protected). This point was partially addressed at the Granada Conference [10], where the building protection was extended also to buildings for which "the protection procedures have been instituted", when proposals for their altering have been planned. This concept, which anyhow does not include historical buildings for which no protection procedure have been instituted, is not present in the EPBD regulation which allow derogation only for already listed buildings. Thus, there is a serious risk of alteration for those historical buildings, not yet protected, which constitute large part of European historical centres and villages, when applying energy measured required for contemporary existing buildings. 
Following the conclusion of [6], when historical or historic buildings are involved, the energy saving has to be seen as one of the several parameters to take into account for a conscious environmental improvement. Thus the energy retrofit has to balance consciously different requirements, i.e. indoor comfort and materials conservation, energy savings and architectonic character of the building. The retrofit materials choice has to be considered on its physical, chemical and mechanical compatibility with existing materials; the retrofitting technologies have to be weighted on their reversibility or less invasiveness, considering the whole environmental impact of each solution.

Coming back to the question on what is 'officially protected' and how this is defined at national level, the real point is if EU can limit the national built heritage to only what is protected or not. The issue is that Cultural Heritage policies are not part of the EU Treaty, while Cultural Heritage is funded and supported by the EU. For this reason, the EU has no competencies in regulating the cultural heritage field. The EU legal acts (directive) that impact negatively on cultural heritage administration and conservation stem from areas inside EU competencies. The negative impact creates an increasing problem for the maintenance and conservation of the cultural heritage following the guidelines outlined in international Treaties, Conventions and Charters, [26]. Thus the only way to regulate in harmonized way the relationship between energy retrofit and historic and historical building is to monitor any development and implementation of those legal acts involving, directly or indirectly, such relationships and to inform all cultural heritage administrations. The cultural heritage sector may, when informed, influence the legal acts in time and on a proactive basis.

\section{Conclusions}

The Energy efficiency in historic buildings is an extremely sensitive issue. Cultural Heritage preservation and energy savings are important issues for Europe, but there is no strong coordinate action at the EU level. Until now, the derogation regime to national transposition laws is the adopted solution for defining if or if not a historic (i.e. protected) building undergoing to some renovation has to comply with the energy efficiency requirements. This is a no-solution because it introduces differences among EU countries in applying energy efficiency requirements to historic buildings. Furthermore, the historically and architectonically valuable buildings not already listed (i.e. not officially protected) are equate to contemporary existing buildings and subjected to their energy efficiency requirements.

In the current state of art of standards and codes, it is possible to highlight the lack of a specific protocol aimed at providing well-balanced solutions for the energy efficiency improvement in historic and historical buildings. Such detachment between building preservation and energy improvement is an institutional issue at the European Union level, because Cultural Heritage policies are not part of the EU Treaty and thus EU cannot directly constraint any national Cultural Heritage Policy. On the other hand, EU directives on energy efficiency, on materials and on other items may strongly affect the Architectural Heritage conservation. One possible solution to overcome such impasse is a correct lobbying activity that 
should be made by all national Bodies responsible for Cultural Heritage. Through this lobbying activity might be possible to steer EU policy in a more effective way towards energy retrofit of historic/historical buildings.

\section{References}

[1] BPIE, Europe’s Buildings under the Microscope. Published by Buildings Performance Institute Europe, 2011

[2] European Parliament, Directive 2002/91/EC of The European Parliament and of the Council of 16 December 2002 on the energy performance of buildings. Official Journal of the European Union. L 1/65, 04.1.2003.

[3] European Parliament, Directive 2010/31/EU of The European Parliament and of the Council of 19 May 2010 on the energy performance of buildings (recast). Official Journal of the European Union. L 153/13, 18.6.2010.

[4] European Parliament, Directive 2012/27/EU of The European Parliament and of the Council of 25 October 2012 on energy efficiency, amending Directives 2009/125/EC and 2010/30/EU and repealing Directives 2004/8/EC and 2006/32/EC. Official Journal of the European Union. L 315/1, 14.11.2012.

[5] Georgia Department of Natural Resources - Historic Preservation Division, What makes a property "historic?" Retrieved January 2014 form http://georgiashpo.org/register

[6] Litti G., Audenaert A., Braet J., Energy Retrofitting in Architectural Heritage, Possible Risks Due to the Missing of a Specific Legislative and Methodological Protocol. ECSEE 2013 - The European Conference on Sustainability, Energy and the Environment 2013. 4th to 7th July 2013, Brighton, United Kingdom.

[7] UNESCO, Convention Concerning The Protection Of The World Cultural And Natural Heritage, adopted by the General Conference at its seventeenth session, Paris, 16 November 1972

[8] Council of Europe, First Conference of European Ministers responsible for the Preservation and Rehabilitation of the Cultural Heritage of Monuments and Sites, Brussels, 25-27 November 1969

[9] Committee of Ministers of the Council of Europe, European Charter of the Architectural Heritage, Amsterdam, October 1975.

[10] Council of Europe, Convention for the protection of the architectural heritage of Europe, Granada, 3.10.1985.

[11] Council of Europe, IV ${ }^{\text {th }}$ European Conference of Ministers responsible for the Cultural Heritage, Helsinki 30-31 May 1996

[12] Council of Europe, $12^{\text {th }}$ Session of the European Conference of Ministers responsible for Regional Planning, Hanover, 7-8 September 2000

[13] Council of Europe, Framework Convention on the Value of Cultural Heritage for Society, Faro, 27 October 2005

[14] Presidenza Repubblica Italiana, Decreto Legislativo 22 gennaio 2004, n. 42, Codice dei beni culturali e del paesaggio, ai sensi dell'articolo 10 Legge 6 luglio 2002, n. 137. GU n.45 del 24-2-2004 - Suppl. Ordinario n. 28. 
[15] Presidenza Repubblica Italiana, D.Lgs. 192/2005, Attuazione della direttiva 2002/91/CE sul rendimento energetico in edilizia. G.U. n. 222 del 23 settembre 2005 S.O. n.158 (come modificato dal D.Lgs. 311/2006, G.U. n. 26 del 1 febbraio 2007 S.O. n.26/L).

[16] Repubblica Italiana, LEGGE 3 agosto 2013, n. 90. Conversione in legge, con modificazioni, del decreto-legge 4 giugno 2013, n. 63, recante disposizioni urgenti per il recepimento della Direttiva 2010/31/UE del Parlamento europeo e del Consiglio del 19 maggio 2010, sulla prestazione energetica nell'edilizia per la definizione delle procedure d'infrazione avviate dalla Commissione europea. G.U. n.181 del 3-8-2013.

[17] Drury P. and McPherson A., Conservation principles, policies and guidance for the sustainable management of historical environments, English Heritage, 2008, London.

[18] Fabbri K., Energy incidence of historic building: Leaving no stone unturned. Journal of Cultural Heritage, vol. 14, no. 3, pp. e25-e27, Jun. 2013.

[19] Ma Z., Cooper P., Daly D., and Ledo L., Existing building retrofits: Methodology and state-of-the-art, Energy and Buildings, vol. 55, pp. 889-902, Dec. 2012

[20] Halliday S., Indoor air quality and energy efficiency in traditional buildings, 2009, Historic Scotland.

[21] English Heritage, Building Regulations and Historic Buildings; Balancing the needs for energy conservation with those of building conservation: an Interim Guidance Note on the application of Part L, 2004, London

[22] Norfolk County Council, Making Old Buildings Energy Efficient, 2008, Norfolk, UK

[23] CEN, Explanation of the general relationship between various European Standards and the Energy Performance of Buildings Directive (EPBD) - Umbrella document. CEN/TR 15615 Technical report. 2008, Brussels, European Committee for Standardization.

[24] English Heritage, PPS5 - Planning for the Historic Environment: Historic Environment Planning Practice Guide, 2010, London

[25] $\mathrm{Co}_{2} \mathrm{olBricks,} \mathrm{Integration} \mathrm{of} \mathrm{Climate} \mathrm{Protection} \mathrm{and} \mathrm{Cultural} \mathrm{Heritage:} \mathrm{Aspects} \mathrm{in} \mathrm{Policy} \mathrm{and} \mathrm{Development} \mathrm{Plans.} \mathrm{Free}$ and Hanseatic City of Hamburg, Department of Heritage Preservation, 2013, Hamburg.

[26] Nypan T., Effects of European Union legislation on the built cultural heritage. Riksantikvaren (Cultural Heritage), Directorate for Cultural Heritage, 2010, Norway.

[27] Secretary of Interior's Standards for Restoration, Guidelines for preserving, rehabilitating, restoring and reconstructing historic buildings, U.S. National Park Service, retrieved January 2014 form http://www.cr.nps.gov/hps/tps/standguide/index.htm

[28] 1200 Buildings, What is a building retrofit?, City of Melbourne, retrieved January 2014 form https://www.melbourne.vic.gov.au/1200buildings/what/Pages/WhatIsRetrofit.aspx 
[29] Presidenza Repubblica Italiana, D.P.R. 380/2001, Testo unico edilizia. G.U. n. 245 del 20 ottobre 2001 S.O. n.239 (come modificato dal D.Lgs. 301/2002, G.U. n.16 del 21 gennaio 2003)

[30] CEN, EN 15898 - Conservation of cultural property - Main general terms and definitions. 2011. Brussels, European Committee for Standardization

\section{APPENDIX A: TERMS AND DEFINITIONS}

The following English definitions are taken from $[27]^{(1)},[28]^{(2)},[9]^{(3)}$ and are consistent with the definitions reported in the Italian Code of Cultural Heritage and Landscape $[14]^{(4)}$ and in the Italian Consolidation Act on Building [29] ${ }^{(5)}$. Those definitions are compared with the CEN Conservation of cultural property definitions [30] ${ }^{(6)}$, when available, taking into consideration that they applies not only to Architectural Heritage conservation. Furthermore, references are made to the source using superscript ${ }^{(\mathrm{x})}$.

\section{Conservation $^{(4)}$}

The preservation of cultural heritage is ensured through consistent, coordinated and planned activities of analysis (assessment), prevention, maintenance and restoration.

Prevention is the set of eligible activities to limit risk situations related to cultural property in its context.

Maintenance means the set of activities and interventions designed to control the conditions of the cultural asset and maintaining the integrity, efficiency and functional identity of the asset and its parts.

Restoration means the direct intervention on the well through a series of operations aiming to the integrity of the material and the recovery of asset itself, to the protection and transmission of its cultural values. In the case of immovable property situated in earthquake-prone areas declared in accordance with current legislation, the restoration includes the intervention of structural improvement.

The CEN definition (CEN, 2011) of conservation is more general: measures and actions aimed at safeguarding cultural heritage while respecting its significance, including its accessibility to present and future generations. Conservation includes preventive conservation, remedial conservation and restoration

\section{Integrated conservation $^{(3)}$}

Integrated conservation is achieved by the application of sensitive restoration techniques and the correct choice of appropriate functions. It should be noted that integrated conservation does not rule out the introduction of modern architecture into areas containing old buildings provided that the existing context, proportions, forms, sizes and scale are fully respected and traditional materials are used. It is a set of measures that are intended to ensure the continuity of an 
heritage, to protect its conservation in the context of a built or natural appropriate environment as well as its destination and its adaptation to the needs of society.

\section{Preservation $^{(1)}$ (American English) - Conservation (British English)}

Preservation is defined as the act or process of applying measures necessary to sustain the existing form, integrity, and materials of an historic property. Work, including preliminary measures to protect and stabilize the property, generally focuses upon the ongoing maintenance and repair of historic materials and features rather than extensive replacement and new construction. New exterior additions are not within the scope of this treatment; however, the limited and sensitive upgrading of mechanical, electrical, and plumbing systems and other code-required work to make properties functional is appropriate within a preservation project.

\section{Preventive conservation $^{(6)}$ (syn. of prevention, Ed.)}

Measures and actions aimed at avoiding or minimizing future damage, deterioration and loss and, consequently any invasive intervention.

\section{Reconstruction $^{(1)}$}

Reconstruction is defined as the act or process of depicting, by means of new construction, the form, features, and detailing of a non-surviving site, landscape, building, structure, or object for the purpose of replicating its appearance at a specific period of time and in its historic location.

The CEN definition (CEN, 2011) is more general: re-establishment of an object to an inferred earlier form using existing or replacement material.

\section{Redevelopment}

Redevelopment is the demolition of old buildings and the creation of new buildings on the same site with a new structure with new dimension and space.

\section{Refurbishment $^{(1)}$}

Refurbishment of a building is the extensive repair, renewal and modification of a building to meet economic and/or functional criteria equivalent to those required by a new building for the same purpose. This may involve the installation of current standard of building services, access, natural lighting, equipment and finishes, using historic fabric as the carcass of what is, effectively, a new building.

Refurbishments are often focussed on aesthetics and tenant amenities, but they can also include upgrades to the building's mechanical systems and can potentially have an effect on energy and water efficiency.

\section{Rehabilitation $^{(1),(5)}$}


(1) Rehabilitation is defined as the act or process of making possible a compatible use for a property through repair, alterations, and additions while preserving those portions or features which convey its historical, cultural, or architectural values.

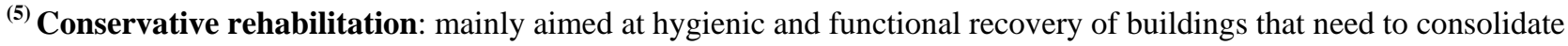
and integrate the structural elements and the modification of the planimetric layout. These interventions may also be carried out with the use of materials and techniques different from the original, as long as consistent with the character of the buildings

The CEN definition (CEN, 2011) is more general: interventions on an immovable object in order to recover an inferred earlier functionality, to adapt it to a different function or to standards of comfort, safety and access.

\section{Remedial conservation $^{(6)}$ (syn. of maintenance, Ed.)}

Actions applied directly to an object to arrest deterioration and/or to limit damage.

\section{Renovation $^{(2),(5)}$}

${ }^{\text {(2) }}$ Renovations are very similar to refurbishments and the terms are sometimes used interchangeably. The major difference is the term renovation applies specifically to buildings, while refurbishment does not. As with refurbishments, renovations are often focussed on aesthetics and tenant amenities, but they may also include upgrades to the building's mechanical systems and potentially have an effect on energy and water efficiency.

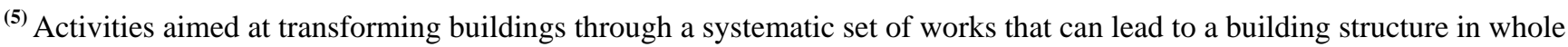
or in part different from the previous. These activities include repairs or replacement of certain elements of the building, removing, modifying and adding new elements and systems. As parts of the building renovations are included even those involving the demolition and reconstruction with the same volume and shape of the existing, subject only to the innovations needed to adapt to the anti-seismic regulations

The CEN definition (CEN, 2011) is just: action of renewing an object without necessarily respecting its material or significance. (CEN, 2011) does not define Refurbishment.

\section{Restoration $^{(1),(5) 2}$}

${ }^{(\mathbf{1})}$ Restoration is defined as the act or process of accurately depicting the form, features, and character of a property as it appeared at a particular period of time by means of the removal of features from other periods in its history and reconstruction of missing features from the restoration period. The limited and sensitive upgrading of mechanical, electrical, and plumbing systems and other code-required work to make properties functional is appropriate within a restoration project.

\footnotetext{
${ }^{2}$ Restoration is different than preservation (conservation) by allowing the removal of historic materials to create an accurate portrayal of a particular time period, not necessarily the original or final time periods.
} 
${ }^{\text {(5) }}$ Restoration is mainly focused on the preservation, recovery and enhancement of the character of buildings of historical and artistic, architectural or environmental interest. These interventions may also be carried out with the use of materials and techniques different from the original, as long as consistent with the character of the buildings.

The CEN definition (CEN, 2011) is: actions applied to a stable or stabilized object aimed at facilitating its appreciation, understanding and/or use, while respecting its significance and the materials and techniques used. NOTE 1: In some professional communities, especially in the field of immovable cultural heritage, the term restoration traditionally covers the whole field of conservation. NOTE 2: Remedial conservation is often carried out at the same time as restoration.

\section{Retro-commission $^{(2)}$}

Commissioning is the process whereby a building's systems are tested and adjusted to ensure they are all functioning as they were designed to. Retro-commissioning, therefore, is performing the same process on a building that has been operational and occupied for a period of time to ensure it keeps meeting the design intent and needs of the occupants. Retrocommissioning or re-commissioning a building once every three to five years is recommended by some experts. If a building wasn't properly commissioned in the first place, if changes to its systems and operating conditions have been made since commissioning, or if its performance has degraded over time it's possible that retro-commissioning can reduce a building's energy consumption by making its existing systems work more efficiently. As with initial commissioning, retrocommissioning can be carried out by the contractors who installed the building's mechanical systems or by a third party who specializes in commissioning.

\section{Retrofit $^{(2)}$}

Retrofitting is the process of modifying something after it has been manufactured. For buildings, this means making changes to the systems inside the building or even the structure itself at some point after its initial construction and occupation. Typically this is done with the expectation of improving amenities for the building's occupants and/or improving the performance of the building. The development of new technologies mean that building retrofits can allow for significant reductions in energy and water usage. 